\title{
UPAYA PENYELESAIAN KREDIT BERMASALAH PADA BANK NAGARI CABANG PEMBANTU TARUSAN
}

\author{
Gusti Rahma Ayu, Ratna Widayati \\ Akademi Keuangan dan Perbankan “ Pembangunan” Padang \\ Ayugustirahma2008@gmail.com
}

\begin{abstract}
The purpose of this study was to determine how the credit settlement efforts at Bank Nagari Pembatu Tarusan Branch. Data collection research methods use two ways, namely library research (Library Research) and field research (Field Research). The results of the study were to find out the causes of problem loans and how to resolve non-performing loans at the bank Tagiri branch.
\end{abstract}

Keywords: settlement, problem loans

\section{PENDAHULUAN}

Untuk memenuhi kebutuhan masyarakat dalam kegiatan produktif dan kegiatan konsumtif lembaga keuangan mempunyai peranan yang sangat penting dalam perkembangan perekonomian masyarakat Indonesia.

Menurut pasal 1 (2) Undang-undang Nomor 10 tahun 1998 tentang Perbankan Bank adalah badan usaha yang menghimpun dana dari masyarakat dalam bentuk simpanan dan menyalurkannya kepada masyarakat dalam bentuk kredit dan atau bentuk-bentuk lainnya dalam rangka meningkatkan taraf hidup rakyat banyak.

Bank sebagai lembaga keuangan berfungsi sebagai financial intermediaries yaitu perantara antara dua belah pihak yang kelebihan dana dan kekurangan dana, dengan cara menghimpun dana dari masyarakat dalam bentuk simpanan dan menyalurkannya kepada masyarakat dalam bentuk kredit yang merupakan kegiatan pokok dari bank atau bentuk lainnya seperti jasa yang merupakan kegiatan pendukung untuk memenuhi otoritas Bank.

Bank Nagari Cabang Pembantu Tarusan adalah cabang pembantu dari Bank Nagari Cabang Painan yang berperan penting untuk pertumbuhan ekonomi di Pesisir Selatan. Keberadaan Bank Nagari Cabang Pembantu ini membantu kegiatan perekonomian masyarakat Tarusan agar dapat mendorong pertumbuhan ekonomi dari berbagai sektor usaha baik industri, perdagangan, pertanian, perkebunan, jasa dan yang bersifat non keuangan lainnya yang membutuhkan bank sebagai mitra dalam mengembangkan ekonominya. Sebagai lembaga keuangan pemerintah daerah yang tugas utamanya memberi kredit maka Bank Nagari Cabang Pembantu Tarusan telah memberikan suatu jalan alternatif kepada masyarakat untuk mendapatkan modal usaha dalam bentuk pinjaman dengan memenuhi syarat dan memberi jaminan.

Kredit Menurut pasal 1 (11) Undang-undang Republik Indonesia Nomor 10 tahun 1998 tentang Perbankan adalah penyediaan uang atau tagihan yang dapat dipersamakan dengan itu, berdasarkan persetujuan atau kesepakatan pinjam- 
meminjam antara bank dengan pihak lain yang mewajibkan pihak peminjam untuk melunasi utangnya setelah jangka waktu tertentu dengan pemberian bunga.

Penyaluran kredit mengandung resiko, yang dapat terjadi karena kelalaian pihak bank dalam menganalisis prinsip kelayakan kredit atau pihak bank kurang teliti dalam mengecek kelengkapan berkas dan dokumen nasabah yang berakibat kredit bermasalah. Permasalahan kredit terjadi karena nasabah tidak dapat memprediksi tingkat ekonomi dan penghasilan yang mereka peroleh dari usaha yang di jalankanya sehingga mengakibatkan kesulitan dalam menyelesaikan kewajiban melunasi utangnya. Oleh karena itu Bank Nagari Cabang Pembantu Tarusan harus cepat menyelesaikan kredit bermasalah yang muncul agar keseimbangan usaha dan kegiatan operasional Bank dapat terjaga. Sehingga tertarik membahasnya dalam Tugas Akhir yang berjudul "Upaya Penyelesaian Kredit Bermasalah Pada Bank Nagari Cabang Pembantu Tarusan”.

\section{Metode Penelitian}

\section{Metode Pengumpulan Data} cara yaitu:

Untuk keperluan penelitian ini, pengumpulan data dilakukan dengan dua

a. Riset kepustakaan (Library Reesearch)

Yaitu mellakukan pengumpulan data melalui cara mempelajari teori-teori dari literatur, karya ilmiah, buku-buku, dan tulisan-tulisan yang ada hubungannya dengan objek penelitian.

b. Riset lapangan (Field Research)

Yaitu peneliti mendapatkan data primer dengan melakukan wawancara atau peninjauan langsung terhadap objek penelitian.

\section{Metode Analisa Data}

Dalam menganalisis suatu data, penulis menggunakan Metode Kualitatif sebagai metode penelitian yang menjelaskan secara deskriptif mengenai penyelesaian kredit bermasalah yang terjadi pada Bank Nagari Cabang Pembantu Tarusan. Metode ini memberi gambaran umum tentang latar belakang penelitian dan sebagai bahan pembahasan yang lebih cenderung mengunakan analisis, dan hasil analisis itu dipergunakan sebagai dasar pengambilan kesimpulan dan saran.

\section{HASIL DAN PEMBAHASAAN Pengertian Kredit}

Kredit Menurut pasal 1 (11) Undang-undang Republik Indonesia Nomor 10 tahun 1998 tentang Perbankan adalah penyediaan uang atau tagihan yang dapat dipersamakan dengan itu, berdasarkan persetujuan atau kesepakatan pinjammeminjam antara bank dengan pihak lain yang mewajibkan pihak peminjam untuk melunasi utangnya setelah jangka waktu tertentu dengan pemberian bunga.

Untuk meningkatkan ekonomi masyarakat atau bisa disebut dengan meningkatkan taraf hidup masyarakat sangat diperlukan pemberian modal berupa kredit, atau investasi dalam bentuk barang dan uang yang bisa digunakan untuk kepentingan nasabah dengan syarat dikembalikan sesuai jangka waktu yang telah disepakati saat pemberian pinjaman.(Indra Rahmatullah, SE.I, 2015) 


\section{Tujuan Pemberian Kredit}

Tidak jauh dari misi bank didirikan pemberian fasilitas kredit memiliki tujuan tertentu pada pelaksanaan kegiatan perbankan yaitu :
a. Meraih Keuntungan
b. Membantu Kebutuhan Usaha Nasabah
c. Membantu Pemerintah

\section{Jenis-Jenis Kredit}

Banyaknya bentuk dan jenis usaha mengakibatkan masyarakat memerlukan modal untuk usaha, sehingga jenis kreditpun menjadi beragam disesuaikan dengan kebutuhan dan tujuan dalam penggunaan dana yang dapat dilihat sebagai berikut:

a. Kredit yang dilihat dari segi kegunaan

1) Kredit Investasi

Kredit investasi ini bermanfaat bagi nasabah untuk penanaman modal agar usaha yang dijalankannya menjadi luas contohnya mendirikan pabrik serta membeli peralatan seperti mesin-mesin dengan ketentuan pendek masa pemakaiannya untuk suatu periode yang relatif lama.

2) Kredit Modal Kerja

Kredit ini sangat diminati banyak pengusaha kecil baik perorangan dan kelompok maupun pengusaha besar perorangan atau kelompok. Karena dapat meningkatkan produksi dalam operasional usaha contohnya modal yang diberikan digunakan untuk pembelian bahan baku, membayar gaji karyawan, pembelian barang dagang untuk mengembangkan usaha, dan biaya-biaya kepentingan lainnya yang berkaitan dengan proses dan produksi perusahaan.

b. Kredit yang dilihat dari segi tujuan

1) Kredit Produktif

Kredit yang ditujukan untuk kepentingan produksi dengan artian luas yaitu meningkatkan usaha, produksi, atau investasi. Kredit ini memberikan manfaat dalam mengahasilkan barang dan jasa agar bertambah meningkat. Contohnya: mendirikan perusahaanyang akan menghasilkan barang seperti pabrik, pertanian, dan pertambangan yang menghasilkan barang tambang.

2) Kredit Konsumtif

Kredit ini pada umumnya digunakan pribadi, tidak menghasilkan barang dan jasa bertambah melainkan fasilitas kredit ini hanya dipakai oleh seseorang ataupun badan usaha yang membutuhkannya. Contohnya: perumahan dan perabotan rumah, dan kendaraan seperti mobil pribadi.

3) Kredit Perdagangan

Biasa digunakan untuk ekspor dan impor, kredit ini diharapkan dapat membayar kewajiban dengan hasil penjualan. Kredit ini digunakan oleh pedagang atau agen yang memebeli barang dalam jumlah besar untuk stok usahanya. 
c. Dilihat dari segi jangka waktu

1) Kredit Jangka pendek adalah kredit yang jangka waktunya kurang lebih dari 1 tahun karena biasanya digunakan sebagai modal kerja contohnya: untuk peternakan dan pertanian.

2) Kredit Jangka Menengah biasa digunakan untuk investasi karena jangka waktunya 1 sampai 3 tahun contohnya untuk pertanian buah.

3) Kredit Jagka Panjang juga digunakan untuk investasi karena jangaka waktu pengembaliannya lama yaitu 3 sampai 5 tahun, contohnya adalah seperti usaha perkebunan: sawit, kelapa, sawit, minyak, timah, tambang emas dan perusahaan manufaktur lainnya.

d. Dilihat dari segi jaminan

1) Kredit dengan jaminan adalah kredit yang akan diberikan kepada pemohon dengan syarat adanya jaminan seperti agunan berupa aset, barang berwujud maupun tidak berwujud dari pihak peminjam. Karena jaminan menjadi faktor pendukung dalam meningkatkan nilai kredit, agar terhindarnya dari resiko kerugian terhadap bank.

2) Kredit Tanpa Jaminan adalah kredit yang diberikan dengan melihat karakter, loyalitas dan prospek usaha yang dijalankan calon peminjam. Kredit ini tidak banyak dipergunakan karena mengandung resiko yang besar bagi perbankan indonesia.(Herman, 2018)

\section{Pengertian Kredit Bermasalah}

Menurut (mantayborbir,2002) kredit bermasalah adalah kredit yang telah jatuh tempo namun belum dilunasi dan tunggakan angsuran lebih dari 279 hari atau 9 bulan. Kredit ini juga dikatakan ketika debitur tidak mampu lagi untuk mengangsur utang pokok dan bunga dari hasil usaha yang dimodali dengan fasilitas kredit.

Menurut ( Rivai,2004) kredit bermasalah adalah kesulitan nasabah di dalam penyelesaian kewajiban-kewajibannya terhadap bank/lembaga keuangan non bank, baik dalam bentuk pembayaran kembali pokoknya, pembayaran bunga, maupun pembayaran ongkos-ongkos bank yang menjadi beban bagi nasabah yang bersangkutan.(Mendari, 2019)

\section{Faktor Penyebab Kredit Bermasalah}

Kredit adalah kegiatan yang penting bagi bank karena dapat meraih keuntungan bagi bank dalam bentuk bunga, dampak buruk akan terjadi bila kredit bermasalah tidak ditangani dengan baik karena kredit bermasalah menggambarkan kegagalan yang mengakibatkan kerugian terhadap bankuntuk itu kredit bermasalah perlu ditangani agar mengurangi terjadinya resiko.

Adapun penyebab atau faktor terjadinya kredit bermasalah :

Menurut (kuncoro dan suhardjono, 2002) kredit bermasalah terjadi karena beberapa faktor berikut:

a. Berdasarkan prospek usaha nasabah

1) Terjadi mogok tenaga kerja yang sangat sulit untuk diatasi.

2) Kelangsungan usaha sangat diragukan dan industri mengalami penurunan dan sulit untuk pulih kembali.

3) Kehilangan pasar sejalan dengan kondisi perekonomian yang menurun dan manajemen yang sangat lemah. 
b. Berdasarkan keuangan debitur

1) Mengalami kerugian besar sehingga debitur tidak mampu memenuhi seluruh kewajiban dan kegiatan usaha tidak dapat dipertahankan.

2) Rasio utang terhadap modal sangat tinggi

3) Pinjaman baru digunakan untuk menutup kerugian operasional

c. Berdasarkan kemampuan membayar

1) Terdapat tunggakan pembayaran pokok dan bunga yang telah melampaui 270 hari.

2) Dokumentasi kredit atau pengikatan agunan tidak ada

Menurut (manan 1993) penyebab yang menjadi sumber munculnya kredit bermasalah berikut :

a. Faktor debitur

b. Faktor Kreditur

c. Faktor Perintah

d. Faktor masyarakat

Menurut (Rivai,2013) kredit bermasalah terjadi karena beberapa penyebab berikut ini :

a. Faktor eksternal bisa juga menjadi penyebab kredit bermasalah karena terjadinya perubahan terhadap political, legal environment, deregulasi sektor real, financial dan ekonomi yang mengakibatkan adanya pengaruh yang merugikan seorang nasabah.

b. Kurang telitinya bank dalam menganalisa kelayakan pemberian kredit seperti pengecekan latar belakang nasabah, Kurang mengadakan kunjungan on the spot pada lokasi perusahaan, Devisikredit atau account officermungkin saja mudah terpengaruhi dan diitimidasi atauoleh calon nasabah, kurang mendalami apa tujuan penggunaan kredit dan dari mana sumber pembayaran untuk melunasi kewajngnya dalam menganalisis laporan keuangan usaha nasabah yang harus memenuhi kelengkapan syarat yang telah ditentukan.

c. Kesalahan juga bisbah itu sendiri seperti nasabah tidak kompeten dalam memahami kredit, tidak mengetahui atau kurangnya pengalaman tentang kredit yang dapat mengakibatkan nasabah tidak mengerti dengan syarat yang diberikan oleh pihak bank.(Mulyadi \& Jubaedah, 2016)

Tujuan Penanganan Kredit Bermasalah Dan Strategi Penanganan Kredit Bermasalah

\section{Tujuan Penyelesaian Kredit Bermasalah}

1. Untuk tetap mempertahankan kondisi bank yang stabi sesuai dengan bussinessplan bank dan/peraturan bank.

2. Untuk memperkecil kerugian bank dengan fokus terhadap penilaian dari kemampuan debitur dalam membayar pinjamannya.

3. Untuk melancarkan perputaran pendapatan bank agar tidak terhambat.

4. Memperoleh kembali dana yang dikeluarkan bank.

5. Meningkatkan kesehatan bank dan menjaga kesinambungan usaha bank. 


\section{Tindakan Penyelamatan Kredit Bermasalah}

Penyelamatan sangat menentukan keberhasilan yang maksimal dalam penyelesaian kredit bermasalah agar kerugian yang diakibatkan kredit bermasalah dapat ditekankan dengan langkah-langkah sebagai berikut :

1) Rescheduling

Suatu usaha penyelamatan kredit dengan cara memperpanjang jangka waktu kelunasan atau perubahan besarnya angsuran pada setiap periode.tindakan ini dapat diberikan jika :

a) Masalah yang dihadapi hanya kesulitan likuiditas sementara.

b) Debitur bersikap kooperatif atau jujur.

c) Menajemen dan sarana produksi berjalan baik.

d) Prospek usaha dapat diharapkan.

e) Penyelamatan lebih baik daripada likuidasi.

2) Reconditioning

Suatu usaha untuk memungkinkan pengembalian hutang oleh debitur dengan cara memberikan keringanan berupa perubahan syaratsyarat, seperti penyesuaian suku bunga. Dalam hal ini tindakan yang diberikan berupa keringanan atau perubahan persyaratan kredi, sebagai berikut:

a) Kapitalisasi bunga, bunga yang dijadikan utang pokok sehingga nasabah dalam waktu tertentu tidak perlu membayar bunga, tetapi hutang pokoknya dapat melebihi plafon yang disetujui. Cara ini ditempuh dalam hal prospek usaha nasabah baik.

b) Penundaan pembayaran bunga, bunga tetap dihitung, tetapi penagihan atau pembebananya pada nasabah tidak dilaksanakan sampai nasabah mempunyai kesanggupan. Berdasarkan bunga yang terhutang tidak dikenakan bunga dan tidak menambah plafon kredit.

c) Penurunan suku bunga, dalam hal nasabah dinilai masih mampu membayar bunga pada waktunya, tetapi suku bunga yang dikenakan terlalu tinggi untuk tingkat aktivitas dan hasil usaha pada waktu itu. Cara ini jalankan jika hasil operasi nasabah memang menunjukan surpluf/laba dan likuiditas memungkinkan untuk membayar bunga.

d) Pembebasan bunga, dalam hal tersebut nasabah memang dinilai tidak sanggup membayar bunga karena usaha nasabah hanya mencapai pulang pokok.

e) Pengkonversasian, disebut dengan kredit jangka pendek menjadi kredit yang jangka panjang dengan syarat yang lebih ringan.

3) Restructuring

Alternatife penyehatan kredit dengan cara menambah modal nasabah dan pertimbangan nasabah memang memutuhkan tambahan dana dan usaha yang dibiayai memang masih layak. Tindakan ini dapat dilakukan dengan cara :

a) Tambahan kredit

Apabila nasabah kekurangan modal kerja, maka perlu dipertimbangkan penanaman modal kerja dan juga dalam hal investasi, baik perluasan maupun tambahan investasi. 
b) Tambahan modal

Apabila tambahan kredit memberatkan nasabah, sehubungan dengan pembayaran bunganya, maka perlu dipertimbangkan tambahan modal sendiri.

4) Kombinasi

Merupakan kombinasi dari ketiga jenis yang diatas. Seseorang nasabah dapat saja diselamatkan dengan kombinasi antara rescheduling dengan restructuring, misalnya jangka waktu diperpanjang pembayaran bunga ditunda atau reconditioning dengan rescheduling misalnya jangka waktu diperpanjang modal di tambah.

Jika tindakan penyelamatan yang telah diberikan bank nagari cabang pembantu tarusan tidak dapat dijalankan debitur benar-benar sudah tidak punya itikad baik ataupun sudah tidak mampu lagi untuk membayar semua hutang-hutangnya maka Penyitaan jaminan adalah jalan terakhir untuk nasabah kredit.

\section{Hasil Penelitian Dan Pembahasan}

Prosedur Pemberian Kredit Pada Bank Nagari Cabang Pembantu Tarusan Tahap Awal Pemberian Kredit

Prosedur Pemberian Kredit Pada Bank Nagari Cabang Pembantu Tarusan melalui tahapan sebagai berikut:

\section{a. Permohonan Kredit}

Pengajuan permohonan kredit ini dilakukan dengan cara nasabah mendatangi kantor Bank Nagari Cabang Pembantu Tarusan terlebih dahulu dan menanyakan tentang kredit apa yang dibutuhkan. Setelah itu nasabah akan diarahkan untuk mengisi formulir yang disediakan petugas kredit dan mengatakan apa saja syarat dan berkas yang harus dibawa setelah mengisi formulir tersebut. Dalam hal ini permohonan kredit secara tertulis dilengkapi dokumen yang disyaratkan sebagai berikut:

1) Fotocopy KTP dan Kartu Keluarga

2) Pas foto

3) Fotocopy Akta pendirian berikut seluruh perubahannya

4) Fotocopy perizinan usaha:

a) NPWP

b) SIUP

c) TDP

d) SITU

5) Fotocopy dokumen jaminan (sertifikat tanah, BPKB, Surat Toko, lainnya)

6) Data-data keuangan (Neraca Dan Laporan laba rugi)

7) Dokumen pendukung lainnya

Dalam mengidentifikasikan permohonan kredit yang diajukan, Bank memiliki kriteria calon debitur sebagai berikut:

a) Warga Indonesia (berusia minimal 21 tahun atau telah menikah dan berakal sehat).

b) Mempunyai penghasilan yang jelas, tetap dan diyakini oleh pihak Bank. 


\section{b. Tahapan Analisis Kredit}

c) Tidak tercatat daftar hitam (black list)

Setelah pihak Bank Nagari Cabang Pembantu Tarusan memeriksa kelengkapan dokumen debitur, pihak bank melanjutkan proses pemberian kredit dengan melakukan analisis cek agunan atau usaha debitur dengan menerapkan prinsip 5C untuk memenuhi syarat pemberian kredit, dengan cara menekankan kelayakan pemberian kredit sesuai prosedur dan kebijakan untuk persetujuan, agar terhindar dari penyimpangan dan ketentuan limit kredit serta pemerintah yang diputuskan oleh kewenangan kredit. Untuk itu nasabah perlu memenuhi prinsip 5C sebagai berikut :

1) Character (Kepribadian)

Bank Nagari Cabang Pembantu Tarusan melihat dan mengetahui bagaimana sifat dan tingkah laku calon nasabah pada kehidupan pribadinya maupun lingkungan usaha yang dijalankannya. Penilaian ini dilakukan dengan melakukan wawancara langsung terhadap calon nasabah pada saat mengajukan permohonan. Agar pihak bank mengetahui sejauh mana kemauan nasabah dalam melunasi kewajibannya setelah pemberian kredit yang sesuai dengan persetujuan dan perjanjian yang ditetapkan pada saat proses permohonan kredit. Berikut alat sebagai pedoman untuk memperoleh latar belakang nasabah anatara lain :

a) Mencari tahu latar belakang kepribadian nasabah apakah tercatat dalam buku hitam atau tidak, nasabah suka berjudi dan berfoyafoya.

b) Meminta referensi catatan pada bank lain apakah nasabah terikat utang pada bank lain

c) Mencari atau meninjau lokasi keberadaan usaha dari calon nasabah

d) Meneliti informasi mengenai riwayat hidup nasabah dan juga meneliti reputasi terhadap lingkungan usaha yang dijalankan calon nasabah.

2) Capital (Modal)

Bank Nagari Cabang Pembantu Tarusan harus mempertimbangkan dana yang diberikan ke calon nasabah kredit dan dilihat dari seberapa besar jumlah dana atau modal yang dimiliki calon nasabah. Bank akan merasa yakin dalam pemberikan kredit kepada nasabah bila telah melihat kesungguhan nasabah menjalankan usahanya, tentu modal akan menjadi pertimbangan bagi bank karena semakin besar modal yang dimiliki nasabah makan akan semakin tinggi kemauan nasabah dalam mengembangkan usahanya.

3) Capacity (Kemampuan)

Bank Nagari Cabang Pembantu Tarusan menilai kemampuan nasabah terhadap kewajibannya membayar dilihat langsung ke lokasi usaha yang akan diberikan kredit. Dengan harapan usaha yang dijalankan nasabah memperoleh pendapatan atau laba serta mencari 
tahu apakah nasabah mengalami masalah krisis ekonomi yaitu keuangan sebelumnya atau tidak.

4) Collateral (Jaminan)

Bank Nagari Cabang Pembantu Tarusan harus melihat sebesar apa jaminan yang akan diberikan oleh calon nasabah kepada bank apakah sesuai dengan besar pinjaman yang diajukan oleh calon nasabah. Ini sangat diperhatikan oleh nasabah karena ketika mereka tidak dapat memenuhi kewajibannya dengan ketentuan dan perjanjian yang telah disepakati jaminan akan disita oleh bank contohnya aset, saham perusahan, sertikat tanah, rumah ataupun kendraan yang bernilai tinggi.

5) Condition of economic (kondisi ekonomi)

Bank Nagari Cabang Pembantu Tarusan harus mempertimbangkan masalah yang dihadapi calon debitur dapat dilihat setelah usahanya dijalankan, prinsip ini dipengaruhi dari beberapa faktor baik dari luar pihak bank ataupun nasabah itu sendiri. Untuk melancarkan kesepakatan kedua belah pihak maka sangat diperlukan adanya komunikasi yang baik antara nasabah dan pihak bank. Karena usaha yang dijalankan nasabah ada pengaruhnya terhadap kondisi perekonomian mikro ataupun makro yang mengakibatkan bank juga mengalami masalah yang sama.

\section{c. Rekomendasi}

Rekomendasi kredit merupakan usulan dan saran dari pejabat kredit ke pemimpin cabang Bank Nagari Cabang Pembantu Tarusan atas permohonan nasabah untuk di setujui atau di tolak oleh pemimpin cabang

\section{d. Keputusan Kredit}

Keputusan pemberian kredit diberikan secara tertulis menggunakan surat pemberitahuan dengan syarat yang ditentukan dan ditanda tangani oleh pemimpin Bank Nagari Cabang Pembantu Tarusan dengan mempertimbangkan analisa kelayakan dan resiko, Apabila keputusan kredit di tolak oleh bank maka akan di sampaikan melalui surat penolakan dari bank.

\section{b. Penandatanganan Akad Kredit/Perjanjian}

Setelah kredit diterima Bank Nagari Cabang Pembantu Tarusan akan menyimpan agunan yang dijadikan jaminan dan pihak debitur diminta mendatangi Bank Nagari Cabang Pembantu Tarusan untuk melakukan perjanjian kredit dengan menandatangani akad kredit.

\section{e. Realisasi Kredit}

Pada Bank Nagari Cabang Pembantu Tarusan realisasi kredit dilakukan melalui rekening tabungan nasabah, jika nasabah belum memiliki rekening di Bank Nagari Cabang Pembantu Tarusan maka nasabah wajib membuka buku tabungan baru atau membuat rekening baru.

\section{f. Tahap Pengawasan Kredit}

Pengawasan berfungsi untuk menjaga keseimbangan dan kekayaan bank serta mengukur dan mengendalikan resiko yang akan terjadi agar lebih efisien sebagai pencegahan terjadinya kredit bermasalah. Teknik 
yang dilakukan Bank Nagari Cabang Pembantu Tarusan adalah menekankan pengawasan yang dilakukan pada awal pemberian, pencairan sampai dengan pelunasan kredit.

\section{Kredit Bermasalah} berikut :

Kredit bermasalah pada Bank Nagari Cabang Pembantu Tarusan sebagai

a. Kredit kurang lancar terjadinya karena ketidak mampunya nasabah dalam membayar hutangnya kepada Bank Nagari Cabang Pembantu Tarusan sesuai dgn waktu yang telah disepakati dengan jangka waktu 3 bulan sampai 6 bulan. Permasalahan yang terjadi yaitu usaha yang dijalankan nasabah mengalami fluktuasi (naik turun).

b. Kredit Diragukan, terjadinya karena ketidak mampunya nasabah dalam membayar hutangnya kepada Bank Nagari Cabang Pembantu Tarusan sesuai dgn waktu yang telah disepakati dengan jangka waktu 6 bulan sampai 12 bulan. Permasalahan yang terjadi yaitu keinginan dan itikad baik nasabah dalam membayar utangnya tidak ada, dimana nasabah mempunyai dana untuk membayar tetapi keinginan untuk memenuhi kewajiban utangnya tidak ada.

c. Kredit macet, terjadinya karena ketidak mampunya nasabah dalam membayar hutangnya kepada bank nagari cabang pembantu tarusan sesuai jangka waktu yang telah disepakati 12 bulan ke atas. Permasalahan yang terjadi yaitu usaha yang dijalankan nasabah mengalami kebangkrutan atau kegagalan dalam mengembangkan usahanya.

Berikut ini adalah jumlah dari keseluhan kredit bermasalah pada Bank Nagari Cabang Pembantu Tarusan :

\section{Tabel 1}

Jumlah Keseluruhan Kredit Bermasalah Pada Bank Nagari Capem Tarusan Dari Tahun 2016-2019

\begin{tabular}{|c|c|c|c|c|}
\hline No & Tahun & $\begin{array}{c}\text { Total Kredit Yang } \\
\text { dicairkan }\end{array}$ & $\begin{array}{c}\text { Total Kredit } \\
\text { Bermasalah }\end{array}$ & $\begin{array}{c}\text { Persentase Kredit } \\
\text { Bermasalah }\end{array}$ \\
\hline 1 & 2016 & 128.844 & 2.361 & $1,83 \%$ \\
\hline 2 & 2017 & 141.471 & 1.901 & $1,34 \%$ \\
\hline 3 & 2018 & 148.900 & 1.828 & $1,22 \%$ \\
\hline 4 & 2019 & 151.632 & 1.721 & $1,13 \%$ \\
\hline
\end{tabular}

Sumber: Bank Nagari Capem Tarusan

Pada tabel di atas dapat dilihat bahwa pada tahun 2016 kredit yang dicairkan sebesar 128.844 juta sedangkan total kredit bermasalah sebesar 2.361 juta dengan persentase kredit sebesar 1,83\%, Pada tahun 2017 kredit yang dicairkan sebesar 141.471 juta sedangkan total kredit bermasalah mengalami penurunan sebesar 1.901 juta dengan persentase kredit sebesar 1,34\%, pada tahun 2018 pencairan kredit meningkat sebesar 148.900 juta sedangkan total kredit bermasalah terus menurun sebesar 1.828 juta dengan persentase kredit sebesar 1,22\%, pada tahun 2019 terjadi pencairan kredit tertinggi sebanyak 151.632 juta sedangkan total kredit bermasalahnya sebesar 1.721 juta lebih kecil dari tahun sebelumnya dengan persentase kredit sebesar $1,13 \%$. 
Kesimpulan tabel diatas adalah dari tahun 2016 sampai dengan 2019 kredit yang diberikan mengalami peningkatan setiap tahunnya dapat dilihat dari total kredit yang dikeluarkan Bank Nagari Cabang Pembantu Tarusan. Sedangkan kredit bermasalah yang terjadi mengalami penurunan setiap tahunnya dikarenakan manajemen kredit yang ada pada Bank Nagari Cabang Pembantu Tarusan sudah cukup baik tetapi belum dapat dikatakan maksimal karena masih ada kredit bermasalah yang terjadi pada Bank Nagari tersebut.

\section{Upaya Penyelesaian Kredit Bermasalah}

Upaya Penyelesaian kredit bermasalah pada Bank Nagari Cabang Pembantu Tarusan sebagai berikut :

a. Teguran dengan telepon

Bank Nagari Cabang Pembantu Tarusan memberi teguran melalui telpon atau sms kepada nasabah yang mengalami kredit bermasalah untuk mengingatkan bahwa angsuran harus segera dibayar agar tidak terjadi pembengkakkan hutang dan denda.

b. Surat Peringatan I (SP I)

Surat peringatan I (SP I) diberikan kepada nasabah kredit yang termasuk kredit dalam kategori kurang lancar, dimana nasabah mulai dianggap tidak dapat melunasi kewajiban utangnya terhadap Bank Nagari Cabang Pembantu Tarusan.

c. Surat Peringatan II (SP II)

Surat peringatan II (SP II) diberikan kepada nasabah kredit yang termasuk kredit dalam kategori diragukan, Bank Nagari Cabang Pembantu Tarusan memberikan Surat Peringatan Kedua (SP II) kepada debitur dengan memberikan keringanan dan cara melunasi sisa kewajiban utangnya. Setelah diberi toleransi diharapkan nasabah membayar sesuai ketentuan dan jangka waktu yang ditetapkan kembali.

d. Surat Peringatan III (SP III) dan Sita Jaminan

Surat peringatan III (SP III) diberikan kepada nasabah kredit yang termasuk kredit dalam kategori macet. nasabah belum melakukan pembayaran atau pelunasan hutang kepada Bank Nagari Cabang Pembantu Tarusan, karena Usaha yang dijalankan nasabah mengalami kebangkrutan atau kegagalan dalam mengembangkan usahanya. Jika sudah diberikan Surat peringatan terakhir (SP III) nasabah belum juga membayar hutang maka Bank Nagari Cabang Pembantu Tarusan melakukan penarikan atas jaminan yang diberikan pada saat pengajuan permohonan kredit. Penarikan atas jaminan akan dilelang untuk melunasi hutang debitur yang ada pada Bank Nagari Cabang Pembantu Tarusan.

\section{Simpulan}

1. Kesimpulan tabel diatas adalah dari tahun 2016 sampai dengan 2019 kredit yang diberikan mengalami peningkatan setiap tahunnya dapat dilihat dari total kredit yang dikeluarkan Bank Nagari Cabang Pembantu Tarusan. Sedangkan kredit bermasalah yang terjadi mengalami penurunan setiap tahunnya dikarenakan manajemen kredit yang ada pada Bank Nagari 
Cabang Pembantu Tarusan sudah cukup baik tetapi belum dapat dikatakan maksimal karena masih ada kredit bermasalah yang terjadi pada Bank Nagari tersebut.

2. Penyebab kredit bermasalah muncul karena faktor external yaitu ketidakmampunya debitur dalam melunasi kewajibannya, adanya tunggakan seperti bunga dan denda yang belum terbayar, serta prospek usaha debitur yang mengalami fluktuasi, dan debitur tidak dapat memprediksi tingkat ekonomi dan penghasilan yang diperoleh dari usaha yang dijalankan. Membuat debitur mulai tidak jujur dalam penggunaan dana apakah untuk membiayai produksi usaha menjadi biaya konsumtif.

3. Upaya penyelesaian kredit bermasalah yang dilakukan Bank Nagari Cabang Pembantu Tarusan yang disesuaikan dengan tingkat permasalahan kredit dikategorikan dalam kredit kurang lancar diberi surat peringatan pertama (SP I), kredit diragukan diberi surat peringatan II ( SPII ), kredit macet diberikan surat peringatan terakhir yaitu ( SP III) berguna untuk mengetahui seberapa besar niat baik debitur dalam melunasi utangutangnya.

\section{DAFTAR PUSTAKA}

Amelia, L., \& Marlius, D. (2018). Pengendalian Kredit Dalam Upaya Menciptakan Bank Yang Sehat Pada PT. Bank Pembangunan Daerah Sumatera Barat Cabang Utama Padang. https://doi.org/10.31227/osf.io/kpc64

Alanshari, F., \& Marlius, D. (2018). Prosedur Pemberian Kredit KPR Pada PT. Bank Tabungan Negara (Persero) TBK Cabang Pembantu Bukittinggi. https://doi.org/10.31227/osf.io/rsfhc

Baiya, \& Fernos, J. (2019). Analisis Faktor-Faktor Penyebab Kredit Macet Pada Bank Nagari Cabang Siteba. https://doi.org/10.31227/osf.io/4xuks

Firmansyah, A. (2015). Analisis Kredit Bermasalah Dilihat Dari Standar Non Performing Loan ( Npl ) Pada Pt . Bank Perkreditan Rakyat ( Bpr ) Prima Mulia. Akademi Keuangan Dan Perbankan "Pembangunan" Padang, 1 of 13.

Herman, U. (2018). Penyelesaian Kredit Bermasalah pada PT. Bank Perkreditan Rakyat (BPR) nagari kasang. 1-14.

Indra Rahmatullah, SE.I, M. (2015). Aset Hak Kekayaan Intelektual Sebagai Jaminan dalam Perbankan. CV Budi Utama.

Ikbal, M., \& Marlius, D. (2017). Pengaruh Jumlah Taksiran Dan Uang Pinjaman Terhadap Laba Bersih Pada PT. Pegadaian (UPC) Gurun Laweh. https://doi.org/10.31227/osf.io/uch4a

Kasmir, D. (2014). Bank Dan Lembaga Keuangan Lainnya. PT. Raja Grafindo Persada.

Mendari, W. E. (2019). Upaya Penanganan Kredit Bermasalah Pada Bank Nagari Cabang Utama Padang. 1-12.

Mulyadi, D., \& Jubaedah, S. (2016). Analisis Manajemen Kredit Dalam Upaya Meminimalkan Kredit Bermasalah (Studi Pada PT. BPR Pantura Abadi 
Karawang). Jurnal Manajemen \& Bisnis Kreatif, 1(1), 1-24. repository.ubpkarawang.ac.id

Tobing, D. D. L. (2009). Penyelesaian Kredit Bermasalah Pada PT.Bank Danamon, Tbk Cabang Semarang.

Widayati, R. (2019). Penyelesaian Kredit Bermasalah Pada PT. Bank Perkreditan Rakyat (BPR) Nagari Kasang. https://doi.org/10.17605/OSF.IO/D4MF3

Widayati, R. (2019). Pelaksanaan Prinsip Kehati-Hatian Dalam Pemberian Kredit

Konsumtif Pada Bank Nagari Cabang Siteba.

https://doi.org/10.17605/OSF.IO/FZVXR

Widayati, R. (2019). Aktivitas Pemberian Kredit Komersil Pada Bank Nagari Cabang Sijunjung. https://doi.org/10.17605/OSF.IO/QTVZ9

Widayati, R. (2019). Pelaksanaan Kredit Pada Bank Perkreditan Rakyat LPN Pasar Baru Durian Sawahlunto. https://doi.org/10.17605/OSF.IO/5HPAB

Widayati, R. (2019). Upaya Penanganan Kredit Bermasalah Pada Bank Nagari Cabang Utama Padang. https://doi.org/10.17605/OSF.IO/YJ3KN

Widayati, R. (2019). Aktivitas Pemberian Kredit Usaha Pada PT. Bank Perkreditan Rakyat Batang Kapas. https://doi.org/10.17605/OSF.IO/EDPN4 